\title{
PENEGAKAN SANKSI ADMINISTRASI TERHADAP APARATUR SIPIL NEGARA YANG MELAKUKAN KEJAHATAN JABATAN OLEH PEJABAT PEMBINA KEPEGAWAIAN PEMERINTAH PROVINSI BENGKULU
}

\author{
Miinudin dan Etry Mike \\ Fakultas Syariah IAIN Bengkulu \\ Jl. Raden Fatah Pagar Dewa Bengkulu \\ Email: Miinudin@gmail.com dan etrymike@gmail.com.
}

\begin{abstract}
The Bengkulu Provincial Government is strongly committed to improving the quality of the Apparatus Resources of bureaucratic reform, especially the reform of apparatus resources within the Regional Government of Bengkulu Province. The ASN task has been regulated in Article 11 of the ASN Law stated that ASN employees are in charge of: a. Carry out public policies made by Personnel Development Officers in accordance with statutory provisions; b. provide professional and quality public services; and c. Strengthen the unity and unity of the Unitary State of the Republic of Indonesia. In order to carry out its duties, violations often occur that might interfere with public services which should be prioritized in carrying out their duties. Government Regulation Number 11 of 2017 concerning Civil Servants Management is regulated regarding dismissal of civil servants without respect if: "convicted with imprisonment or confinement based on a court decision that has permanent legal force because of a crime of occupation crime or crime related to General position and/or criminal.
\end{abstract}

Keywords: Enforcement, Sanctions, Administration, State Civil Apparatus, Position Crimes

\begin{abstract}
Abstrak: Pemerintah Provinsi Bengkulu berkomitmen kuat untuk meningkatkan kualitas Sumber Daya Apatur reformasi birokrasi khususnya reformasi sumber daya aparatur di lingkungan Pemerintah Daerah Provinsi Bengkulu. Tugas ASN telah diatur pada Pasal 11 UU ASN dinyatakan bahwa Pegawai ASN bertugas: a. Melaksanakan kebijakan publik yang dibuat oleh Pejabat Pembina Kepegawaian sesuai dengan ketentuan peraturan perundangundangan; b. Memberikan pelayanan publik yang profesional dan berkualitas; dan c. Mempererat persatuan dan kesatuan Negara Kesatuan Republik Indonesia.Dalam rangka menjalankan tugasnya sering terjadi pelanggaranpelanggaran yang mungkin mengganggu pelayanan publik yang seharusnya lebih diutamakan dalam menjalankan tugasnya. Peraturan Pemerintah Nomor 11 Tahun 2017 tentang Manajemen Pegawai Negeri Sipil diatur tentang pemberhentian PNS tidak dengan hormat apabila: "dipidana dengan pidana penjara atau kurungan berdasarkan putusan pengadilan yang telah memiliki kekuatan hukum tetap karena melakukan tindak pidana kejahatan Jabatan atau tindak pidana kejahatan yang ada hubungannya dengan Jabatan dan/atau pidana umum.
\end{abstract}

Kata Kunci : Penegakan, Sanksi, Administrasi, Aparatur Sipil Negara, Kejahatan Jabatan 
AL-IMARAH: Jurnal Pemerintahan dan Politik Islam

Vol. 3, No. 1, 2018

\section{Pendahuluan}

Pegawai Aparatur Sipil Negara yang selanjutnya disebut Pegawai ASN adalah pegawai yang berfungsi sebagai pelaksana kebijakan publik, pelayan publik, dan perekat dan pemersatu bangsa, sebagaimana tecantum pada Pasal 10 Undang-Undang Republik Indonesia Nomor 5 Tahun 2014 tentang Aparatur Sipil Negara (UU ASN).

Sudah banyak kemajuan yang dialami oleh pemerintah di bidang kepegawaian, yang mana sebelumnya kinerja pegawai negeri dinilai berdasarkan sistem patron (patronage system) dimana prestasi dan kerja lebih diutamakan beralih ke sistem merit ${ }^{1}$ (merit system) dimana kompetensi dan kinerja pegawai lebih diutamakan. Namun demikian masih saja terjadi pelanggaran-pelanggaran sanksi administrasi maupun pidana.

Tugas ASN telah diatur pada Pasal 11 UU ASN dinyatakan bahwa Pegawai ASN bertugas: a. Melaksanakan kebijakan publik yang dibuat oleh Pejabat Pembina Kepegawaian sesuai dengan ketentuan peraturan perundang-undangan; b. Memberikan pelayanan publik yang profesional dan berkualitas; dan c. Mempererat persatuan dan kesatuan Negara Kesatuan Republik Indonesia.

${ }^{1}$ Pasal 1 angka 22 UU Nomor 5 Tahun 2017 Tentang ASN menyatakan bahwa Sistem Merit adalah kebijakan dan Manajemen ASN yang berdasarkan pada kualifikasi, kompetensi, dan kinerja secara adil dan wajar dengaan tanpa membedakan latar belakang politik, ras, warna kulit, agama, asal usul, jenis kelamin, status pernikahan, umur, atau kondisi kecacatan.
Dalam rangka menjalankan tugasnya sering terjadi pelanggaran-pelanggaran yang mungkin mengganggu pelayanan publik yang seharusnya lebih diutamakan dalam menjalankan tugasnya. Sebagai abdi negara dan abdi masyarakat tentunya pegawai ASN yang berasal dari PNS pada saat diangkat menjadi PNS wajib mengucapkan sumpah/janji”, pelanggaran terhadap tugas dan/atau sumpah/janji PNS merupakan pelanggaran yang sering terjadi.

Pada Pasal 21 UU ASN, diatur hak PNS, sedangkan pada Pasal 23 UU ASN diatur kewajiban pegawai ASN. Sebagai Pegawai ASN, maka PNS dapat menuntut haknya, tetapi dia juga harus menjalankan kewajibannya, dan untuk menumbuhkan kepatuhan PNS.

\section{Pasal 87 ayat (4)b UU ASN} menyatakan bahwa PNS diberhentikan tidak dengan hormat karena : "Dihukum penjara atau kurungan berdasarkan putusan pengadilan yang telah memiliki kekuatan hukum tetap karena melakukan tindak pidana kejahatan jabatan atau tindak pidana kejahatan yang ada hubungannya dengan jabatan dan/atau pidana umum".

Pada Pasal 250 huruf b Peraturan Pemerintah Nomor 11 Tahun 2017 tentang Manajemen Pegawai Negeri Sipil diatur tentang pemberhentian PNS tidak dengan hormat apabila: "dipidana dengan pidana penjara atau kurungan berdasarkan putusan pengadilan yang telah memiliki kekuatan 
hukum tetap karena melakukan tindak pidana

kejahatan Jabatan atau tindak pidana kejahatan yang ada hubungannya dengan Jabatan dan/atau pidana umum".

Data Komisi Aparatur Sipil Negara (KASN) menunjukkan, saat ini ada 594 ASN yang tengah menjalani hukuman penjara karena tindak pindana kejahatan jabatan. Angka itu dinilai belum mewakili gambaran sesungguhnya di lapangan. Jumlah ASN yang dipenjara karena kasus korupsi diyakini lebih besar. Sebelumnya, Badan Kepegawaian Daerah Regional XI di Manado menemukan ada 83 dari 145 ASN berstatus terpidana korupsi yang masih menerima gaji dan tunjangan dari pemerintah.

Bagaimana dengan Provinsi Bengkulu, Per Desember 2017 Total ASN yang tengah menjalani hukuman kasus Tipikor sebanyak 504 orang dan Provinsi Bengkulu ada di posisi 2(dua) teratas setelah Provinsi DKI jakarta yaitu sebanyak 32 Orang. Ketua KASN Sofia Effendi mengatakan, temuan itu hanyalah puncak dari fenomena gunung es. Jumlahnya mungkin lebih besar. Keengganan instansi untuk melapor membuat temuan ini tergolong sangat kecil. Komisioner KASN, Tasdik Kinanto, mengungkapkan, perbedaan persepsi di antara para pejabat pembina kepegawaian, mulai dari gubernur, bupati dan walikota, bahkan hingga kepala dinas, menjadi sebabnya. ${ }^{2}$ Sebanyak 36 orang PNS di

\footnotetext{
${ }^{2}$ Koran Manado, Ibid.
}

lingkungan Pemerintah Provinsi (Pemprov) Bengkulu bermasalah. ${ }^{3} \quad$ Kasus Fatmawati adalah salah satu contoh kasus ASN yang menjadi terpidana karena tindak pidana kejahatan jabatan dan telah diberhentikan oleh Gubernur Bengkulu. Namun dari kasus itu pulalah mencuat kasus serupa, tetapi tidak diberhentikan. Fatmawati menggugat Gubernur Bengkulu ke Pengadilan Tata Usaha Negara, namun kalah dan Fatmawati berhenti menjadi PNS.

Berdasarkam materi gugatan Fatmawati terungkap ada PNS yang masih bekerja dan masih menerima gaji meskipun telah menjalani hukuman penjara karena menjadi terpidana tindak pindana kejahatan jabatan, negara /daerah berpotensi dirugikan. Pembayaran gaji dan tunjangan terhadap ASN yang berstatus terpidana tindak pindana kejahatan jabatan berpotensi merugikan keuangan negara.Reformasi ASN dimana negara dalam keadaan darurat tindak pindana kejahatan jabatan, sebagaimana Indonesia merupakan negara hukum maka siapapun harus patuh dan tunduk pada hukum apalagi jika sampai menimbulkan keruagian Keuangan Negara.

Undang-Undang Nomor 5 Tahun 2014 tentang Aparatur Sipil Negara pada Pasal 94 ayat (4) seperti yang dilansir dari laman situs www.setkab.go.id berbunyi: "Penyusunan 3 Anonymous, 36 PNS Bengkulu bermasalahhttp:www.bengkulunews.co.id/12-pns-dipecat-23-lagi-dalam-proses, diunduh pada tanggal 14 November 2017. 
AL-IMARAH: Jurnal Pemerintahan dan Politik Islam Vol. 3, No. 1, 2018

kebutuhan jumlah PPPK sebagaimana dimaksud dilakukan untuk jangka waktu minimal 5 (lima) tahun yang diperinci per 1 (satu) tahun berdasarkan prioritas kebutuhan, dan ditetapkan dengan keputusan menteri." Undang-Undang ini menegaskan, setiap Warga Negara Indonesia mempunyai kesempatan yang sama untuk melamar menjadi calon PPPK setelah memenuhi persyaratan yang telah ditentukan. Pengadaan dalam rangka penerimaan pendaftaran lowongan PPPK sebagaimana dimaksud, dilakukan melalui tahapan perencanaan, pengumuman lowongan, pelamaran, seleksi, pengumuman hasil seleksi, dan pengangkatan menjadi PPPK. Adapun penerimaannya dilakukan melalui penilaian secara objektif berdasarkan kompetensi, kualifikasi, kebutuhan instansi pemerintah, dan persyaratan lain yang dibutuhkan dalam jabatan. $^{4}$

Sebelum dilantik menjadi PNS/ ASN, seseorang diwajibkan mengucapkan sumpah sesuai dengan agama dan keyakinannya, seperti yang diatur Pada Pasal 39 Peraturan Pemerintah Nomor 11 Tahun 2017 tentang Manajemen Pegawai Negeri Sipil dan Pasal 40 Peraturan Pemerintah Nomor 11 Tahun 2017 tentang Manajemen Pegawai Negeri Sipil. Melanggar sumpah jabatan dikenakan sanksi, baik sanksi administrasi maupun sanksi pidana.

4 Bambang Rudito et. al., Aparatur Sipil Negara Pendukung Reformasi Birokrasi, Kencana, Jakarta, 2016, h. 103-104.

49
Berdasarkan latar belakang di atas, penulis tertarik mengadakan penelitian yang berkaitan dengan sanksi terhadap ASN yang melanggar sumpah/janji yang telah diucapkan pada saat pelantikan menjadi PNS, yaitu sanksi administrasi, dengan judul: "PENEGAKAN SANKSI ADMINISTRASI TERHADAP APARATUR SIPIL NEGARA YANG MELAKUKAN KEJAHATAN JABATAN OLEH PEJABAT PEMBINA KEPEGAWAIAN PEMERINTAH PROVINSI BENGKULU”.

\section{Pembahasan}

a) Penegakan Sanksi Administrasi Oleh Pejabat Pembina Kepegawaian Terhadap ASN Yang Melakukan Tindak Pidana kejahatan Jabatan.

Di dalam penegakan hukum atau sanksi administrasi dapat dilakukan baik secara preventif maupun secara represif. Tindakan preventif, yaitu tindakan yang dilakukan oleh pihak yang berwajib sebelum penyimpangan sosial terjadi agar suatu tindak pelanggaran dapat diredam atau dicegah. Pengendalian yang bersifat preventif pada umumnya dilakukan dengan cara melalui bimbingan, pengarahan, atau ajakan. $^{5}$

Gunawan Graha menyatakan bahwa dalam arti luas proses penegakan hukum itu melibatkan semua subjek hukum. Siapa saja

${ }^{5}$ Anonymous,http://globespotes.blogspot.co.id/ 2014//08/s dah-dapat-dicopy.html, Pengertian Tindakan Preventef, represif, kuratif beserta contohnya, diunduh tanggal 17 Januari 2018, h. 1. 
yang menjalankan aturan hukum normatif atau melakukan sesuatu atau tidak melakukan sesuatu dengan berdasarkan diri pada norma hukum yang berlaku, berarti dia menjalankan atau menegakkan hukum. ${ }^{6}$

Menurut Jonlar Purba $^{7}$, faktor yang berhubungan dengan Penegakan Hukum masyarakat berpengaruh terhadap penegakan hukum atau penegakan peraturan perundang-undangan. Hal ini dinyatakan dalam kutipan berikut:

"Adapun penegakan hukum merupakan faktor yang harus diperhatikan dalam hal penegakan peraturan perundang-undangan antara lain sebagai berikut:

1) Faktor hukum atau peraturan perundangundangan.

2) Faktor aparat penegak hukumnya, yakni pihak-pihak yang terlibat dalam proses pembuatan dan penerapan hukumnya, yang berkaitan dengan masalah mentalitas.

3) Faktor sarana atau fasilitas yang mendukung proses penegakan hukum.

Faktor masyarakat, yakni lingkungan sosial dimana hukum tersebut berlaku atau diterapkan; berhubungan dengan kesadaran dan kepatuhan hukum

\footnotetext{
${ }^{6}$ Gunawan Graha, Pedoman Ilmu "Pengertian Penegakan Hukum dalam Masyarakat", file:/Users/user/Document/Pengertian\%20Penegakan\%2 0Hukum\%20dalam\%20Masyarakat $\% 20 \$ 20$ Pengertian \%20ILMU.html, diunduh tanggal 18 Januari 2018, h.. 3.

${ }^{7}$ Jonlar Purba, Penegakan Hukum Terhadap Tindak Pidana Bermotif Ringan Dengan Restorative Justice, Jala Permata Aksara, Jakarta, 2017, h. 42.
}

yang merefleksi perilaku masyarakat.Faktor kebudayaan, yakni hasil karya, cipta dan rasa yang didasarkan pada karsa manusia di dalam pergaulan hidup."

Badan Kepegawaian Daerah adalah unsur pendukung tugas Gubernur, dipimpin oleh seorang Kepala yang berkedudukan dibawah dan bertanggung jawab kepada Gubernur melalui Sekretaris Daerah. Badan Kepegawaian Daerah Provinsi mempunyai tugas pokok melaksanakan penyusunan dan pelaksanaan kebijakan daerah dibidang kepegawaian aparatur daerah. ${ }^{8}$

Terkait dengan pelaksanaan peningkatan reformasi birokrasi khususnya reformasi sumber daya aparatur di lingkungan Pemerintah Daerah Provinsi Bengkulu sangat memerlukan adanya perubahan manajemen kepegawaian yang mampu mendukung pembangunan tata pemerintahan yang demokratis, desentralistis, dan dinamis, serta ekonomi pasar sosial yang semakin terbuka, sehingga perlu dibangun ASN Daerah Bengkulu yang memiliki kekuatan dan kemampuan serta daya saing yang semakin tinggi dan semakin mampu melaksanakan pencapaian tujuan dan program Pemerintah dan Pemerintah Daerah.

$$
\text { Pada Pemerintah Provinsi }
$$

Bengkulu, masalah kepegawaian daerah

\footnotetext{
8 Anonymous, Rencana Strategis Badan Kepegawaian Daerah Provinsi Bengkulu Tahun 20162021, Badan Kepegawaian Daerah Provinsi Bengkulu, Bengkulu, 2016, h. 7.
} 
diurus oleh Badan Kepegawaian Daerah Provinsi Bengkulu, yang merupakan Organisasi Perangkat Daerah yang dibentuk khusus untuk menangani urusan kepegawaian daerah Provinsi Bengkulu. Tujuan yang dirumuskan Badan Kepegawaian Daerah Provinsi Bengkulu dalam melaksanakan manajemen kepegawaiannya adalah "Meningkatnya profesionalisme Aparatur" di Provinsi Bengkulu sebagaimana yang diharapkan.

Pasal 87 ayat (4) huruf b UU ASN yang menentukan pada pokoknya PNS diberhentikan tidak dengan hormat karena dihukum penjara atau kurungan berdasarkan putusan pengadilan yang berkekuatan hukum tetap karena melakukan tindak pidana kejahatan jabatan atau tindak pidana yang ada hubungannya dengan jabatan dan/atau pidana umum.

Penerapan Pasal 87 ayat (4) huruf b UU ASN seharusnya wajib dilaksanakan bagi PNS yang dijatuhi hukuman penjara berdasarkan putusan pengadilan yang berkekuatan hukum tetap karena melakukan tindak pidana jabatan atau tindak pidana kejahatan yang ada hubungannya dengan jabatan harus diberhentikan tidak dengan hormat dengan tanpa mempertimbangkan lama tidaknya PNS tersebut dijatuhi hukuman penjara.

Pada Pasal 362 Peraturan Pemerintah Nomor 11 Tahun 2017 tentang Manajemen Pegawai Negeri Sipil, dinyatakan bahwa "Pada saat Peraturan Pemerintah ini mulai berlaku, dicabut dan dinyatakan tidak berlaku sejumlah Peraturan Pemerintah dan mengamanatkan pembentukan Peraturan Pemerintah yang baru sebagai peraturan pelaksanaannya. ${ }^{9}$

Berdasarkan hasil penelitian diperoleh data sebanyak 13 orang ASN diberhentikan dan 23 orang ASN yang belum diberhentikan, jika dikelompokkan maka dapat dilihat yang sudah diberhentikan pada Tabel 2 berikut: Tabel 2. Pegawai Negeri Sipil yang melakukan Tindak Pidana Kejahatan Jabatan Pada Pemerintah Provinsi Bengkulu (Sudah Diberhentikan) ${ }^{10}$

\begin{tabular}{clllc}
\hline No & \multicolumn{1}{c}{$\begin{array}{c}\text { Nama } \\
\text { Terpidana }\end{array}$} & Gol & $\begin{array}{l}\text { Tanggal } \\
\text { Putusan }\end{array}$ & Ket. \\
\hline 1 & $\begin{array}{l}\text { Ir. Moch. } \\
\text { Karyamin }\end{array}$ & III/d & $\begin{array}{l}18 \text { Maret } \\
2015\end{array}$ & $\begin{array}{c}\text { Sud } \\
\text { ah }\end{array}$ \\
\hline 2 & Abu Hasan & & 27 Maret & Sud \\
& Azhari, & III/c & 2015 & ah \\
& S.Pi. & & & \\
\hline 3 & Ir. & & 27 Maret & Sud \\
& Bismalinda, & IV/a & 2015 & ah \\
& M.Si. & & & \\
\hline 4 & Adrianto & & 24 & Sud \\
& Himawan, & III/c & Agustus & ah \\
& S.E. & & 2015 & \\
\hline 5 & Edi Santoni, & & 26 & Sud \\
& S.Sos., & IV/a & Oktober & ah \\
& M.Kes. & & 2015 & \\
\hline 6 & Ir. & & 07 & Sud \\
& Fatmawati & IV/a & September \\
& & & 2016 & ah \\
\hline & & & & \\
\hline
\end{tabular}

\footnotetext{
${ }^{9}$ Pasal 362 Peraturan Pemerintah Nomor 11 Tahun 2017 tentang Manajemen Pegawai Negeri Sipil.
} 


\begin{tabular}{|c|c|c|c|c|}
\hline 7 & $\begin{array}{l}\text { Jawawi, } \\
\text { S.T. }\end{array}$ & $\mathrm{III} / \mathrm{d}$ & $\begin{array}{l}16 \\
\text { September } \\
2016\end{array}$ & $\begin{array}{l}\text { Sud } \\
\text { ah }\end{array}$ \\
\hline 8 & $\begin{array}{l}\text { Yenni } \\
\text { Arfianti, } \\
\text { B.P.A. }\end{array}$ & $\mathrm{III} / \mathrm{b}$ & $\begin{array}{l}28 \\
\text { September } \\
2016\end{array}$ & $\begin{array}{l}\text { Sud } \\
\text { ah }\end{array}$ \\
\hline 9 & $\begin{array}{l}\text { Ir. Rinaldi, } \\
\text { M.M. }\end{array}$ & $\mathrm{IV} / \mathrm{c}$ & $\begin{array}{l}14 \\
\text { Oktober } \\
2016\end{array}$ & $\begin{array}{l}\text { Sud } \\
\text { ah }\end{array}$ \\
\hline 10 & $\begin{array}{l}\text { Devi } \\
\text { Maryani, } \\
\text { S.Sos. }\end{array}$ & $\mathrm{III} / \mathrm{c}$ & $\begin{array}{l}20 \\
\text { Desember } \\
2016\end{array}$ & $\begin{array}{l}\text { Sud } \\
\text { ah }\end{array}$ \\
\hline 11 & $\begin{array}{l}\text { Buyung } \\
\text { Mutahan, } \\
\text { S.T. }\end{array}$ & $\mathrm{III} / \mathrm{d}$ & $\begin{array}{l}20 \text { Maret } \\
2017\end{array}$ & $\begin{array}{l}\text { Sud } \\
\text { ah }\end{array}$ \\
\hline 12 & $\begin{array}{l}\text { Untung, } \\
\text { S.T. }\end{array}$ & $\mathrm{III} / \mathrm{c}$ & $\begin{array}{l}20 \quad \text { Maret } \\
2017\end{array}$ & $\begin{array}{l}\text { Sud } \\
\text { ah }\end{array}$ \\
\hline 13 & $\begin{array}{l}\text { Hendri } \\
\text { Sumantri, } \\
\text { A.M. KL. }\end{array}$ & $\mathrm{III} / \mathrm{d}$ & $\begin{array}{l}23 \\
\text { Desember } \\
2017\end{array}$ & $\begin{array}{l}\text { Sud } \\
\text { ah }\end{array}$ \\
\hline
\end{tabular}

Sumber Data: BKD Provinsi Bengkulu tanggal 20 Maret s/d 20 April 2018

Menurut Peraturan Kepala Badan Kepegawaian Negara Nomor 21 Tahun 2010 dan Keputusan Presiden Nomor 53 tahun 2014, Pemberhentian 13 orang ASN diatas mulai dari sidang baperjakat yang mana diikuti oleh Sekretaris Daerah Provinsi Bengkulu sebagai ketua Baperjakat, Asisten Administrasi Umum, Kepala BKD, Inspektur Daerah Provinsi Bengkulu, Kepala Biro Hukum, Kepala BPKAD melalui rapat tertutup disampaikan dan dirapatkan bersama menindak lanjuti 36 orang ASN Provinsi Bengkulu terpidana tindak pidana Kejahatan Jabatan yang mana sudah di terbitkannya putusan pengadilan, kemudian nama-nama tersebut di laporkan ke Pejabat Pembina
Kepegawaian Provinsi Bengkulu sampai dengan terbitnya keputusan gubernur tentang pemberhentian terbukti melakukan pelanggaran tindak pidana kejahatan jabatan, maka akan direkomendasikan untuk pemberhentian. Jika berdasarkan hasil pemeriksaan terbukti melanggar disiplin tingkat berat, maka Gubernur memberhentikan ke 12 terpidana tersebut dan mengusulkan pemberhentian satu orang terpidana yaitu Ir Rinaldi, M.M. golongan ruang IV/c, yang berdasarkan Keputusan Presiden Nomor 53 Tahun 2014 untuk PNS golongan ruang IV/c ke atas diberhentikan oleh Kepala Badan Kepegawaian Negara atas nama Presiden dan untuk 23 orang ASN lainnya masih menunggu Proses Pemberhentian status sebagai PNS.

Berhubung Peraturan Pemerintah yang mengatur mengenai penilaian kinerja dan penjatuhan hukuman sanksi administrasi PNS sebagaimana dimasud dalam Pasal 228 dan Pasal 229 Peraturan Pemerintah Nomor 11 Tahun 2017 tentang Manajemen Pegawai Negeri Sipil belum terbentuk, maka dapat dipahami bahwa untuk penegakan disiplin Aparatur Sipil Negara tetap berpedoman pada Peraturan Pemerintah Nomor 53 Tahun 2010 tentang Disiplin Pegawai Negeri Sipil. Pasal 6 Peraturan Pemerintah Nomor 53 Tahun 2010 tentang Disiplin Pegawai Negeri Sipil menyatakan bahwa "Dengan tidak mengesampingkan ketentuan dalam peraturan perundang-undangan pidana, PNS yang 
AL-IMARAH: Jurnal Pemerintahan dan Politik Islam Vol. 3, No. 1, 2018

melakukan pelanggaran disiplin dijatuhi hukuman disiplin.

Fakta bahwa Pemerintah Provinsi Bengkulu merupakan tempat bernaung para narapidana tindak pindana kejahatan jabatan dari kabupaten/kota di Provinsi Bengkulu seperti Rahmat Eka Wijaya, Dr. Herawansyah, M.Sc., M.T., dan lain-lain, dimana Dr. Herawansyah, M.Sc. M.T. sebelumnya adalah PNS pada Pemerintah Kota Bengkulu, kemudian pindah ke Pemerintah Kabupaten Seluma, dan akhirnya ikut berkumpul pada Pemerintah Provinsi Bengkulu.

Menurut Pasal 87 ayat (2) UU ASN, PNS dapat diberhentikan dengan hormat tidak atas permintaan sendiri apabila dijatuhi pidana penjara yang sudah mempunyai kekuatan hukum tetap. Sedangkan Pasal 229 ayat (3) Peraturan Pemerintah Nomor 11 tahun 2017 tentang Manajemen Pegawai Negeri Sipil, menyatakan PNS yang yang melakukan pelanggaran disiplin dijatuhi hukuman disiplin.

Menurut Pasal 6 Peraturan Pemerintah Nomor 53 Tahun 2010 tentang Disiplin Pegawai Negeri Sipil seharusnya tanpa mengesampingkan putusan pidana, PNS yang melanggar disiplin dijatuhkan hukuman disiplin. Artinya, Pejabat Pembina Kepegawaian Daerah Provinsi Bengkulu dapat menjatuhkan hukuman disiplin disamping hukuman pidana yang sudah diputus oleh Pengadilan.

Mengenai adanya Terpidana yang sudah mempunyai kekuatan hukum tetap tetapi tidak dijatuhi hukuman disiplin, menurut penulis didasarkan kepada rasa kemanusiaan, mereka patuh hukum hanya menunggu waktu, proses tetap berjalan. Dapat dipahami bahwa pertimbangan untuk tidak memberhentikan PNS yang melakukan pelanggaran disiplin adalah pertimbangan kemanusiaan, namun sesuai dengan data dan fakta yang ada sudah diberhentikan dan ada yang belum, makanya ada gugatan ke Pengadilan Tata Usaha Negara. Berdasarkan studi dokumen yang dilakukan terdapat data bahwa memang proses pemberhentian sedang berjalan, hanya menunggu waktu.

Dengan demikian, berdasarkan data di atas, dapat dipahami bahwa Pejabat Pembina Kepegawaian Provinsi Bengkulu yaitu Gubernur Bengkulu tidak tegas dalam upaya Penegakan Sanksi administrasi terhadap ASN yang melakukan kejahatan jabatan pada Pemerintah Provinsi Bengkulu.

b) Akibat Hukum Tidak Menegakkan Sanksi Administrasi Aparatur Sipil Negara

Pegawai Negeri Sipil yang melakukan pelanggaran disiplin dijatuhi hukuman disiplin oleh pejabat yang berwenang menghukum. ${ }^{11}$ Kewenangan penegakan disiplin disebut juga kekuasaan formal yaitu

\footnotetext{
${ }^{11}$ Sedarmayanti ,Manajemen Sumber Daya Manusia, Reformasi Birokrasi, dan Manajemen Pegawai Negeri Sipil, PT. Refika Aditama, Bandung, h. 400.
} 
kekuasaan legislatif atau kekuasaan eksekutif administrasi. $^{12}$

Dalam UU ASN dibedakan mana pejabat yang berwenang dan mana Pejabat Pembina Kepegawaian, meskipun UndangUndang Nomor 43 Tahun 1999 tentang Perubahan Undang-Undang Nomor 8 Tahun 1974 tentang Pokok-Pokok Kepegawaian tidak membedakan secara implisit. Yang dimaksud dengan Pejabat yang Berwenang adalah pejabat yang mempunyai kewenangan melaksanakan proses pengangkatan, pemindahan, dan pemberhentian pegawai ASN sesuai dengan ketentuan peraturan yang berlaku. Sedangkan yang dimaksud dengan Pejabat Pembina Kepegawaian adalah "pejabat yang mempunyai kewenangan menetapkan pengangkatan, pemindahan, dan pemberhentian pegawai ASN dan pembinaan ASN di instansi pemerintah sesuai dengan ketentuan peraturan perundang-undangan yang berlaku.

Adapun tujuan penjatuhan hukuman sanksi administrasi berdasarkan Lampiran I Peraturan Kepala Badan Kepegawaian Negara Nomor 21 Tahun 2010 tentang Ketentuan Pelaksanaan Peraturan Pemerintah Nomor 53 Tahun 2010 tentang Disiplin Pegawai Negeri Sipil pada

12 Harun Arsyad dan Sukamto, Kewenangan Pengangkatan, Pemindahan, dan Pemberhentian PNS, Modul Diklat Analis Kepegawaian, Pusat Pembinaan Jabatan Fungsional Kepegawaian Badan Kepegawaian Negara, Jakarta, 2014, h. 3. prinsipnya bersifat pembinaan yaitu untuk memperbaiki dan mendidik PNS yang melakukan pelanggaran disiplin agar yang bersangkutan mempunyai sikap menyesal dan berusaha tidak mengulangi serta memperbaiki diri pada masa yang akan datang. Juga dimaksudkan agar PNS lainnya tidak melakukan pelanggaran disiplin.

Apabila seorang Pejabat Pembina Kepegawaian Daerah yang dalam hal ini Kepala Daerah/Gubernur tidak menerapkan ketentuan peraturan perundang-undangan berpedoman pada Undang-Undang Nomor 23 tahun 2014 tentang Pemerintah Daerah, maka Pejabat Pembina Kepegawaian dapat diberi sanksi berupa teguran tertulis oleh Menteri Dalam Negeri dan apabila teguran tertulis tidak dindahkan sebanyak dua kali, maka dilakukan pembinaan kepada Pejabat Pembina Kepegawaian tersebut. Dewan Perwakilan Rakyat Daerah (DPRD) Provinsi juga dapat menggunakan hak interpelasi dan apabila penjelasan kepala daerah terhadap penggunaan hak interpelasi DPRD tidak diterima, DPRD Provinsi dapat melaporkan Gubernur kepada Menteri Dalam Negeri. Dan apabila sanksi telah disampaikan dua kali berturut-turut dan tidk dilaksanakan, kepala daerah diwajibkan mengikuti program pembinaan khusus. ${ }^{13}$

\footnotetext{
${ }^{13}$ Pasal 73 Undang-Undang Nomor 23 Tahun 2014 tentang Pemerintahan Daerah, sebagaimana telah beberapa kali diubah, terakhir dengan Undang-Undang
} 
AL-IMARAH: Jurnal Pemerintahan dan Politik Islam Vol. 3, No. 1, 2018

Penegakan terhadap aturan hukum merupakan bagian dari kesadaran hukum masyarakat. Hal itu sejalan dengan pendapat M. Solly Lubis yang menyatakan bahwa:

"Kesadaran hukum yang dimaksud di sini adalah paduan sikap mental dan tingkah laku terhadap masalah-masalah yang mempunyai segi hukum, jadi meliputi:

Nomor 9 Tahun 2015 tentang Perubahan Kedua Atas Undang-Undang Nomor 23 Tahun 2014 tentang Pemerintahan Daerah, menyatakan bahwa:

(1) Kepala daerah yang tidak menyampaikan laporan penyelenggaraan Pemerintahan Daerah sebagaimana dimaksud dalam Pasal 70 ayat (4) dan ringkasan laporan penyelenggaraan Pemerintahan Daerah sebagaimana dimaksud dalam Pasal 72 dikenai sanksi administratif berupa teguran tertulis oleh Menteri untuk gubernur dan oleh gubernur, sebagai wakil Pemerintah Pusat, untuk bupati/wali kota.

(2) Dalam hal teguran tertulis sebagaimana dimaksud pada ayat (1) telah disampaikan 2 (dua) kali berturut-turut dan tetap tidak dilaksanakan, kepala daerah diwajibkan mengikuti program pembinaan khusus pendalaman bidang pemerintahan yang dilaksanakan oleh Kementerian serta tugas dan kewenangannya dilaksanakan oleh wakil kepala daerah atau oleh pejabat yang ditunjuk.

(3) Dalam hal kepala daerah tidak melaksanakan kewajiban menyampaikan laporan keterangan pertanggungjawaban sebagaimana dimaksud dalam Pasal 71 ayat (2), DPRD provinsi dapat menggunakan hak interpelasi kepada gubernur dan DPRD kabupaten/kota dapat menggunakan hak interpelasi kepada bupati/wali kota.

(4) Apabila penjelasan kepala daerah terhadap penggunaan hak interpelasi sebagaimana dimaksud pada ayat (3) tidak diterima, DPRD provinsi melaporkan gubernur kepada Menteri dan DPRD kabupaten/kota melaporkan bupati/wali kota kepada gubernur sebagai wakil Pemerintah Pusat.

(5) Berdasarkan laporan dari DPRD sebagaimana dimaksud pada ayat (4), Menteri memberikan sanksi teguran tertulis kepada gubernur dan gubernur sebagai wakil Pemerintah Pusat, memberikan sanksi teguran tertulis kepada bupati/wali kota.

(6) Apabila sanksi sebagaimana dimaksud pada ayat (5) telah disampaikan 2 (dua) kali berturut-turut dan tetap tidak dilaksanakan, kepala daerah diwajibkan mengikuti program pembinaan khusus pendalaman bidang pemerintahan yang dilaksanakan oleh Kementerian serta tugas dan kewenangannya dilaksanakan oleh wakil kepala a) pengetahuan mengenai seluk beluk hukum, b) penghayatan atau internalisasi terhadap nilai-nilai keadilan dan c) ketaatan atau kepatuhan (obedience) terhadap aturan hukum yang berlaku."14 Seperti diutarakan oleh M. Solly Lubis di atas, kesadaran hukum pada umumnya ditandai oleh tiga hal yakni: ${ }^{15}$

a) Tingkat pengetahuan mengenai seluk beluk hukum yang berlaku, baik hukum yang tertulis maupun hukum yang tidak tertulis, tegasnya semua aturan baik yang ditetapkan secara resmi dari pihak pemerintah maupun pranata-pranata sosial yang hidup dalam masyarakat itu.

b) Tingkat penghayatan atau pengertian mengenai peranan-peranan hukum yakni untuk apa perlunya hukum dalam rangka pemeliharaan tertib sosial, baik di lingkungan kecil maupun besar. Tingkat ketaatan atau kepatuhan terhadap hukum-hukum yang berlaku.

Dalam Undang-Undang Nomor 31 Tahun 1999 tentang Pemberantasan Tindak pidana Korupsi sebagaimana telah diubah oleh undang-Undang Nomor 20 Tahun 2001 tentang Perubahan Atas Undang-Undang Nomor 31 tahun 1999 tentang Pemberantasan Tindak pidana Korupsi, terdapat 30 jenis

\footnotetext{
${ }^{14}$ M. Solly Lubis, Politik dan Hukum di Era Reformasi, CV. Mandar Maju, Bahan Bacaan Mata Kuliah Perspektif Hukum Pancasila, Program Pascasarjana Ilmu Hukum Fakultas Hukum Universitas Bengkulu, Bengkulu, 2012, h. 31.

${ }^{15}$ Ibid., h. 32.
} 
tindak pidana korupsi yang dikelompokkan menjadi tujuh kategori :
a. Kerugian Keuangan Negara;
b. Suap-menyuap;
c. Penggelapan dalam Jabatan;
d. Pemerasan;
e. Perbuatan curang;
f. Benturan kepeningan dalam pengadaan;
g. Gratifikasi

Dalam hal ini dikatakan bahwa kerugian negara dapat terjadi karena pelanggaran hukum akibat kelalaian Pejabat Pembina Kepegawaian dalam rangka pelaksanaan kewenangan yang tidak tegas dalam penyelesaian kerugian keuangan negara yang ditimbulkan dimana 23 orang ASN yang belum dijatuhi hukuman pemberhentian sebagai PNS kasus tindak pindana kejahatan jabatan dan masih berstatus PNS aktif.

Akibat hukum bagi ASN pada Pemerintah Provinsi Bengkulu yang melanggar disiplin dan tidak dijatuhi hukuman disiplin, mengakibatkan produk-produk yang dihasilkan oleh ASN yang bersangkutan baik berupa pemikiran maupun hasil pekerjaan fisik menjadi tidak sah. Pasal 70 ayat.(1) huruf a Undang-Undang Nomor 30 Tahun 2014 tentang Adminstrasi Pemerintahan menyatakan bahwa "Keputusan dan/atau Tindakan tidak sah dibuat oleh Badan dan/atau Pejabat Pemerintahan yang tidak berwenang". Karena cacat hukum maka hasil pekerjaannya menjadi tidak sah dan tidak berhak mendapatkan haknya sebagai PNS seperti yang terdapat pada Pasal 21 Undang-Undang Nomor 5 Tahun 2014 tentang Aparatur Sipil Negara. Dengan demikian dapat dipahami bahwa 23 orang yang tidak dijatuhi hukumaan disiplin pemberhentian pada Pemerintah Provinsi Bengkulu dapat memperburuk citra Pemerintah Provinsi Bengkulu di mata publik.

Pegawai ASN yang seharusnya diberhentikan tetapi masih tetap bekerja ditinjau dari hak dan kewajiban Pegawai ASN sudah tidak memungkinkan lagi untuk melakukan tindakan atas nama ASN/PNS, dalam hal ini terjadi perbedaan kedudukan sebelum dan sesudah dijatuhi hukuman. Setelah dijatuhi hukuman seharusnya tidak lagi ada kewajibannya sebagai ASN/PNS. Jika mereka bertindak mengatasnamakan ASN/PNS, maka dapat dikategorikan sebagai ASN/PNS gadungan. Tujuan penjatuhan hukuman disiplin berdasarkan Lampiran I Peraturan Kepala BKN adalah pada prinsipnya adalah bersifat pembinaan yaitu untuk memperbaiki PNS yang melakukan pelanggaran disipilin agar yang bersangkutan mempunyai sikap menyesal dan dan berusaha tidak mengulangi serta memperbaiki diri pada masa yang akan datang. Juga dimaksudkan agar PNS yang lain tidak melakukan pelanggaran disiplin.

Berkaitan dengan adanya Pegawai ASN yang melanggar disiplin tingkat berat pada Pemerintah Provinsi Bengkulu karena 
menjadi terpidana kasus kejahatan jabatan yang belum diberhentikan, sedangkan mereka masih menerima gaji tersebut dapat dijelaskan berdasarkan pemahaman sebagai beikut:

1. Akibat hukum adalah akibat suatu tindakan yang dilakukan untuk memperoleh suatu akibat yang dikehendaki oleh pelaku dan yang diatur oleh hukum. Tindakan yang dilakukannya merupakan tindakan hukum yakni tindakan yang dilakukan guna memperoleh sesuatu akibat yang dikehendaki hukum. ${ }^{16}$

2. Akibat hukum adalah segala akibat yang terjadi dari segala perbuatan hukum yang dilakukan oleh sumyek hukum terhadap obyek hukum atau akibat-akibat lain yang disebabkan karena kejadian-kejadian tertentu oleh hukum yang bersangkutan telah ditentukan atau dianggap sebagai akibat hukum. ${ }^{17}$

Dengan demikian Pegawai ASN Pemerintah Provinsi Bengkulu yang telah dihukum tidak berhak lagi menerima gaji dikarenakan yang bersangkutan seharusnya terhitung sejak dijatuhkan hukuman oleh Pengadilan harus diberhentikan, atau gaji yang diterimanya menjadi tidak sah secara hukum serta dapat menimbulkan kerugian keuangan negara bila terjadi demikian maka akan muncul tindak pidana baru / Korupsi. Sejalan dengan itu bahwa akibat hukum merupakan

16 R. Soeroso dalam Ahmad Rifa'i, Akibat Hukum,file://C:/Users/user/Documents/Akibat\%20Huk um.htm, diunduh tanggal 6 Mei 2018, h. 1.

${ }^{17}$ Pipin Syarifin dalam Ahmad Rifa'i, Ibid. sumber lahirnya hak dan kewajiban bagi subyek-subyek hukum yang bersangkutan.

\section{Penutup}

\section{Simpulan}

Pejabat Pembina Kepegawaian Daerah Provinsi Bengkulu yang dalam hal ini adalah Gubernur Bengkulu tidak tegas dalam penegakan sanksi administrasi terhadap ASN yang melanggar kejahatan jabatan oleh Pejabat Pembina Kepegawaian pada Pemerintah Provinsi Bengkulu. Hal ini terlihat dari 36 orang pelanggar yang dikenakan sanksi, hanya 13 orang / 33,33\% yang dijatuhi hukuman disiplin berupa pemberhentian dengan hormat tidak atas permintaan sendiri dan pemberhentian tidak dengan hormat sebagai PNS, berarti kurang dari $50 \%$. Akibat hukum terhadap Pejabat Pembina Kepegawaian yang tidak menegakkan Sanksi yaitu Pejabat tersebut dapat dikenakan sanksi administrasi dari Menteri Dalam Negeri berupa teguran dan pembinaan. Pejabat tersebut juga dapat diusulkan oleh DPRD Provinsi Bengkulu berdasarkan hak interpelasi Dewan untuk dijatuhi hukuman disiplin. Dasar hukumnya adalah Pasal 73 UndangUndang Nomor 23 tentang Pemerintahan Daerah. Akibat hukum bagi ASN yang tidak patuh yaitu semua hasil kerja ASN tersebut menjadi tidak sah atau cacat hukum karena dianggap sudah tidak berwenang. Terhadap gaji yang diterima 
Miinudin dan Etry Mike:

Penegakan Sanksi Administrasi Terhadap Aparatur Sipil Negara Yang Melakukan Kejahatan Jabatan Oleh Pejabat Pembina Kepegawaian Pemerintah Provinsi Bengkulu

ASN yang seharusnya diberhentikan adalah tidak sah dan melanggar hukum karena dianggap sudah tidak mempunyai hak dan kewajiban.

\section{Saran}

Pejabat Pembina Kepegawaian atau Pejabat yang Bertanggung Jawab agar dapat menegakkan Hukum terhadap ASN yang melakukan tindak pidana kejahatan jabatan dan diberhentikan dengan tidak hormat. Kepada PNS yang melakukan pelanggaran agar segera mengundurkan diri sebagai PNS. Hal ini berkaitan dengan gaji yang diterima karena di anggap sudah tidak sah dan berpotensi menjadi tindak pidana kejahatan jabatan.

\section{Pustaka Acuan}

\section{Buku-Buku}

Anonymous, Rencana Strategis Badan Kepegawaian Daerah Provinsi Bengkulu Tahun 2016-2021,(Badan Kepegawaian Daerah Provinsi Bengkulu, Bengkulu, 2016)

Bambang Rudito et. al., Aparatur Sipil Negara Pendukung Reformasi Birokrasi, (Jakarta:Kencana, 2016)

Harun Arsyad dan Sukamto, Kewenangan Pengangkatan, Pemindahan, dan Pemberhentian PNS, (Modul Diklat Analis Kepegawaian, Pusat Pembinaan Jabatan Fungsional Kepegawaian Badan Kepegawaian Negara, Jakarta, 2014)
Jonlar Purba, Penegakan Hukum Terhadap Tindak Pidana Bermotif Ringan Dengan Restorative Justice, (Jakarta: Jala Permata Aksara, 2017)

M. Solly Lubis, Politik dan Hukum di Era Reformasi, (CV. Mandar Maju, Bahan Bacaan Mata Kuliah Perspektif Hukum Pancasila, Program Pascasarjana Ilmu Hukum Fakultas Hukum Universitas Bengkulu, Bengkulu, 2012)

Sedarmayanti, Manajemen Sumber Daya Manusia, Reformasi Birokrasi, dan Manajemen Pegawai Negeri Sipil, (Bandung: PT. Refika Aditama, 2017)

\section{Internet}

Anonymous, 36 PNS Bengkulu bermasalah, http:www.bengkulunews.co.id/12-pnsdi-pecat-23-lagi-dalam-proses, diunduh pada tanggal 14 November 2017.

Anonymous,

http://globespotes.blogspot.co.id/2014// 08/sudah-dapat-dicopy.html,

Pengertian Tindakan Preventef, represif, kuratif beserta ccontohnya, diunduh tanggal 17 Januari 2018.

Gunawan Graha, Pedoman Ilmu "Pengertian Penegakan Hukum dalam Masyarakat", file:/Users/user/Document/Pengertian\% 20Penegakan\%20Hukum\%20dalam\%2 0Masyarakat\%20\$20Pengertian\%20IL MU.html, diunduh tanggal 18 Januari 2018. 
AL-IMARAH: Jurnal Pemerintahan dan Politik Islam

Vol. 3, No. 1, 2018

Anonymous, Rencana Strategis Badan

Kepegawaian Daerah Provinsi

Bengkulu Tahun 2016- 2021, (Badan

Kepegawaian Daerah Provinsi

Bengkulu, Bengkulu, 2016)

Soeroso dalam Ahmad Rifa'i, Akibat Hukum,

file:///C:/Users/user/Documents/Akibat

\%20Hukum.htm, diunduh tanggal 6

Mei 2018

\section{Peraturan Perundang-undangan}

Undang-Undang Republik Indonesia Nomor 5

Tahun 2017 tentang Aparatur Sipil

Negara.

Peraturan Pemerintah Nomor 11 Tahun 2017

tentang Manajemen Pegawai Negeri

Sipil.

Undang-Undang Nomor 23 Tahun 2014

tentang Pemerintahan Daerah,

sebagaimana telah beberapa kali

diubah, terakhir dengan Undang-

Undang Nomor 9 Tahun 2015 tentang

Perubahan Kedua Atas Undang-

Undang Nomor 23 Tahun 2014 tentang

Pemerintahan Daerah. 